\title{
$\begin{array}{lllllllllllllllll}\mathbf{R} & \mathbf{O} & \mathbf{Z} & \mathbf{P} & \mathbf{R} & \mathbf{A} & \mathbf{W} & \mathbf{Y} & \text { I } & \text { A } & \mathbf{R} & \mathbf{T} & \mathbf{Y} & \mathbf{K} & \mathbf{U} & \mathbf{L} & \mathbf{Y}\end{array}$
}

Ks. Ginter Dzierżon

Ius Matrimoniale 30 (2019) $\mathrm{nr} 4$

DOI:10.21697/im.2019.30.4.01

Wydział Prawa Kanonicznego UKSW

ORCID: 0000-0002-5116-959X

\section{Status małżeństw nieważnych z powodu zaistniałej przeszkody lub braku formy kanonicznej w kanonicznym porządku prawnym (kan. $1107 \mathrm{KPK})$}

Treść: Wstęp. 1. Specyfika hipotezy ujętej w kan. 1107 KPK. 2. Domniemanie co do trwania zgody małżeńskiej. 2.1. Założenia generalne. 2.2. Możliwość konwalidacji małżeństwa. 3. Odwołanie wyrażonej zgody. Zakończenie.

\section{Wstęp}

Rozdział IV Księgi IV „Uświęcające zadania Kościoła” wieńczy kan. 1107 KPK, który stanie się przedmiotem naszego zainteresowania w tym opracowaniu. Zapisano w nim: „Chociaż małżeństwo zostało zawarte $\mathrm{z}$ racji przeszkody lub braku formy, to jednak domniemywa się, że wyrażona zgoda trwa, dopóki nie uzyska się pewności co do jej odwołania”. Na marginesie należy dodać, iż w Kodeksie z 1917 roku w analogicznym w kan. 1093 zawarto jedynie hipotezę dotyczącą zaistnienia przeszkody zrywającej ${ }^{1}$; również w prawie rzymskim rozpatrywano ten kazus ${ }^{2}$. Wydaje się, iż na dodanie kolejnego komponentu, jakim jest brak formy kanonicznej, wpłynęła jurysprudencja

\footnotetext{
1 Por. kan. 1093 CIC/17: „Etsi matrimonium invalide ratione impedimenti initum fuerit, consensus praestitus praesumitur perseverare, donec de eius revocatione constiterit".

2 Por. O. RobledA, El matrimonio en derecho Romano, Roma 1970, s. 113.
} 
rotalna. Otóż w orzeczeniu c. Turnaturi z 1 marca 2002 roku ponens nawiązał do wyroku c. Felici z 8 lipca 1954 roku, w którym jego redaktor rozważył kwestię trwania konsensu małżeństw cywilnych zawartych z pominięciem formy kanonicznej ${ }^{3}$.

\section{Specyfika hipotezy ujętej w kan. 1107 KPK}

Jedno z pryncypiów kanonicznego systemu prawa małżeńskiego wyartykułowano w zasadzie, zgodnie z którą wyrażona przez nupturientów ważna zgoda małżeńska nie może zostać przez nich odwołana (kan. $1057 \$ 2 \mathrm{KPK})^{4}$. Należy jednak zauważyć, iż ustalenie zawarte w kan. 1107 KPK odbiega od tego rozwiązania, ponieważ prawodawca $\mathrm{w}$ hipotezie ujętej w tej regulacji przyzwala na odwołanie uprzednio wyrażonego przez nupturientów konsensu. W kanonie tym bowiem

3 Por. Dec. c. Turnaturi z 1.03.2002, RRDec., vol. XCIV, s. 93 i 93, n. 8 i 10: „Supra relata confirmationem inveniunt in una coram Felici qui tenet pro validitate consensus naturalis prestiti in matrimonio civili non ad formalitates sed ad interiorem animi statum recurrendum: «Quotiescumque igitur cadit quaestio de valore consensus emissi in ritu civili, sive agitur de iis, qui lege clandestinitatis non tenentur, sive agitur de examinanda perseverantia consensus pro concessione sanationis in radice, non unus ritus civilis prae oculis habendus est, quasi hic, de se tantum, evincat cum certitudine legitimitatem consensus: sed simul, imo et praecipue, exploranda est mens illius qui ritui civili se subiecit. Unde, etsi inter sponsos lege clandestinitatis non ligatos, et matrimonium religiosum negligentes, praesumptio stet pro matrimonii valore, praesertim si, ut inter protestantes, ipsa eorum religio valorem tribuat matrimonio civili (cfr. S. Officii, Ep. ad Archiep. Coloniensem, diei 2 iulii 1892; S.R. Rota, in una Nullitatis Matrimonii, diei 30 iunii 1922, coram Prior): huiusmodi tamen non est nisi praesumptio, ita ut sit in singulis casibus diligenter exploranda mens contrahentis» (sent. diei 8 iunii 1954, ibid., vol. XLVI, p. 459, n. 6). Re, dum vetus Codex Iuris Canonici consensus perseverantiam admittebat tantum in casu impedimenti (can. 1093), nunc vigens Codex agnoscit quoque in casu defectus formae: «Etsi matrimonium invalide ratione impedimenti vel defectus formae initum fuerit, consensus praestitus praesumitur perseverare, donec de eius revocatione constiterit» (can. 1107)".

4 Por. L. Chiappetta, Il matrimonio nella nuova legislazione canonica e concordataria, Roma 1996, s. 260; F. Bersini, Il diritto canonico matrimoniale. Commento giuridico-teologico-pastorale, Torino19944 ${ }^{4}$, s. 142. 
idzie wprawdzie o konsens ważnie powzięty, ale nieważny z powodu wystąpienia przeszkody zrywającej bądź braku formy kanonicznej. W tym wypadku oba komponenty struktury prawnej małżeństwa są równouprawnione, to znaczy nie ma znaczenia czy małżeństwo jest nieważne z powodu przeszkody zrywającej, czy braku formy ${ }^{5}$. W tym wypadku bowiem znajduje aplikację kan. 1100 KPK, w myśl którego znajomość lub opinia o nieważności małżeństwa niekoniecznie wyklucza zgodę małżeńskąa .

Kontynuując, trzeba dodać, iż istotnym komponentem dyspozycji kan. 1107 KPK jest trwanie wyrażonej zgody małżeńskiej. W tym kontekście szczególnym przedmiotem namysłu komentatorów stanowi kwestia wyrażonej zgody, określona w normie jako consensus praestitus. Podejmując ten problem na początku trzeba stwierdzić, iż zgodnie z założeniami systemowymi konsens, o którym mowa winien spełniać wymogi określone w kan. $1104 \$ 1-2$ KPK. Według tej regulacji nupturienci powinni być równocześnie obecni osobiście lub przez pełnomocnika; samą zgodę natomiast winni wyrazić słowami; w sytuacji natomiast gdy nie mogą mówić - równoznacznymi znakami ${ }^{7}$. Należy podkreślić, iż zapis ten odnosi się do efektu formalnego ${ }^{8}$.

Komentatorzy zwracają uwagę, iż pod interesującą nas kategorię nie podpadają z jednej strony zamiar zawarcia małżeństwa, z drugiej zaś wszystkie akty poprzedzające samo zawarcie związku9. Zauważamy więc, iż consensus praestitus, o którym mowa w kan. 1107 KPK

5 Por. K. Lüdicke, Heiligungsamt: Ehe, w: K. LüdICKE (red.), Münsterischer Kommentar zum Codex Iuris Canonici, t. 4, Essen 1985, ad. 1107 n. 2.

6 Szerzej na ten temat zob. J.A. NiEva García, Conocimiento u opinión acerca de nulidad del proprio matrimonio y consentimiento matrimonial, Roma 2003, s. 469-473.

7 Por. G. DzIERżon, Forma wyrażenia zgody małżeńskiej określona w kan. 1104 \$S 1-2 KPK, Ius Matrimoniale 28 (2017) nr 3, s. 3-16.

8 Por. O. Robleda, El matrimonio..., dz. cyt., s. 223.

9 Por. P.J. Viladrich, Konsens małżeński. Sposoby prawnej oceny i interpretacji w kanonicznych procesach o stwierdzenie nieważności małżeństwa, tłum. S. Świaczny, Warszawa 2002, s. 465. 
ma inną fizjonomię, niż zgoda małżeńska zdefiniowana w kan. 1057 $\$ 2$ KPK.

Prezentowane zagadnienie należałoby jeszcze rozpatrzyć z aspektu teoretycznoprawnego. Mianowicie w hipotezie ujętej w kan. 1107 KPK idzie o konsens ważnie wyrażony, ale prawnie nieskuteczny ${ }^{10}$. Przeszkody zrywające bowiem, wyłączając przeszkody pochodzące z prawa natury lub prawa Bożego pozytywnego, jak i wymogi dotyczące formy kanonicznej są komponentami dodanymi przez prawodawcę kościelnego do ważności aktu prawnego, jakim jest małżeństwo (kan. $124 \$ 1 \mathrm{KPK})$.

Należy jeszcze raz powtórzyć, iż nie ulega wątpliwości, iż ustalenia przyjęte w kan. 1107 KPK znacznie odbiegają od pryncypium generalnego jakim jest zasada nieodwoływalności konsensu. W tym wypadku bowiem zawarty przez kontrahentów związek obiektywnie jest nieważny z powodu niezachowania jednego bądź kilku komponentów do dodanych przez prawodawcę do ważności aktu (kan. 124 $\$ 1 \mathrm{KPK})$. Jednocześnie zakłada się, iż małżonkowie trwają w tym związku w „dobrej wierze” ${ }^{11}$. W przyjętym rozwiązaniu nawiązano do zasady określonej w kan. $124 \$ 2$ KPK, w myśl której „domniemywa się ważność aktu prawnego w jego elementach istotnych”. Implementacja tej zasady w kan. 1107 KPK znalazła odzwierciedlenie w domniemaniu co do trwania zgody małżeńskiej.

10 Por. J. Hendriks, Diritto matrimoniale. Commento ai canoni 1055-1165 del Codice di diritto canonico, Milano 1998, s. 223; P. BIANCHI, Commento al. can. 1107, w: Redazione di Quaderni della Mendola (red.), Codice di Dirittoa Canonico commentato, Milano 2017, s. 920.

${ }^{11}$ Por. W. GórAlski, Komentarz do kan. 1107 KPK, w: J. KrUkowski (red.), Komentarz do Kodeksu Prawa Kanonicznego, t.III/2, Poznań 2011, s. 310. 


\section{Domniemanie co do trwania zgody małżeńskiej}

\subsection{Założenia generalne}

Ustawodawca w komentowanym kan. 1107 KPK wprowadził domniemanie co do trwania zgody małżeńskiej, postanawiając: „domniemywa się, że wyrażona zgoda trwa, dopóki nie uzyska się pewności jej odwołania". Trwanie konsensu nie ma charakteru czasowego, ale bezterminowy ${ }^{12}$.

Rozpoczynając analizę tej kwestii należy zauważyć, iż w wyroku c. McKey z 4 kwietnia 2005 roku wyliczono tę presumpcję obok kilku innych domniemań funkcjonujących w materialnym prawie małżeńskim, takich jak: domniemanie o braku ignorancji po osiągnięciu dojrzałości (kan. $1096 \S 2 \mathrm{KPK}$ ) oraz domniemanie określone w kan. $1101 \S 1 \mathrm{KPK}$ dotyczące symulacji1 ${ }^{13}$.

Odnosząc się do charakteru tego domniemania kanoniści podkreślają, iż w tym przypadku idzie o presumpcję iuris tantum. Oznacza to zatem, iż można ją obalić dowodem przeciwnym ${ }^{14}$. Według Viladricha ratio tego rozwiązania nie należy upatrywać $\mathrm{w}$ woli ustawodawcy zmierzającej do potrzymania stabilności węzła małżeńskiego; w jego opinii w kan. 1107 KPK ma miejsce podporządkowanie zasadzie konsensualnej. Jego zdaniem presumpcja ta nie stoi w opozycji do zasady konsensualności, ale jak to określił, „ochrona małżeńskiej

\footnotetext{
12 Por. P.J. Viladrich, Konsens małżeński..., dz. cyt., s. 468.

13 Por. Dec. C. McKey z 4.02.2005, RRDec., vol. XCVII, s. 74-75, n. 11: „Exposita doctrina, Codex iuris canonici de re necessarias statuit præsumptiones: puberes igitur obiectum essentiale consensus non ignorare præsumuntur (can. $1096 \$ 2$ ), consensus coram significatus conformis præsumitur animo contrahentium (can. $1101 \S 2$ ), consensus semel - etsi etiam invalide - expressus præsumitur perseverare donec de eius revocatione reapse constet (can. 1107). Præsumptio vero conformitatis de qua in præfato canone 1101 in nostro casu momentum habet omnino particulare quia necessarie derivatur a distinctione facienda inter actum humanum eiusque manifestationem".

14 Por. L. Chiappetta, Il matrimonio..., dz. cyt., s. 260; L. SAbBarese, Il matrimonio canonico nell'ordine della natura e della grazia. Commento al Codice di Diritto Canonico. Libro IV, Parte I, Titolo VII, Roma 2016, s. 295.
} 
natury i skutków społecznych łącznej woli nupturientów [...], stanowi quidditas zgody"15. W hipotezie określonej w analizowanej normie zachodzi przewaga konsensu wyrażonego nad przeszkodami zrywającymi oraz formą kanoniczną ${ }^{16}$.

Komentując zapis kan. 1107 KPK Luigi Chiappetta celnie zauważył, iż trwanie związku nie odnosi się do małżeństwa in fieri, gdyż tego typu akt ma charakter przejściowy i nie może trwać; trwa natomiast konsens wyrażony w swoim wymiarze prawno-moralnym, jako stan woli; substancjalnie zaś jako intencja habitualna mieszcząca się w obszarze matrimonium in facto esse ${ }^{17}$.

\subsection{Możliwość konwalidacji małżeństwa}

Wprowadzenie domniemania w kan. 1107 KPK nie wyklucza możliwości konwalidacji nieważnego małżeństwa ${ }^{18}$. Poruszając ten problem kanoniści z reguły wymieniają uzdrowienie w zawiązku (kan. 1161-1165 KPK) ${ }^{19}$; Paolo Bianchi wskazał jeszcze na konwalidację sekretną (kan. 1158 i $1159 \$ 2 \mathrm{KPK})^{20}$. Zastosowanie tych instytucji staje się jedynie możliwe wtedy, jeśli małżeństwo zostało zawarte, gdy idzie o fizjonomię, w formie prawnej (formgerecht), przy założeniu, iż wyrażony konsens trwa ${ }^{21}$. Takie rozwiązanie zostało zawarte w kan. 1139 \$1 CIC/17, zgodnie z którym „Każde małżeństwo zawarte poprzez wyrażenie zgody naturalnie wystarczającej lecz prawnie

\footnotetext{
15 Por. P.J. Viladrich, Konsens małżeński..., dz. cyt., s. 467-468.

16 Por. TAmŻE, s. 468.

17 Por. L. Chiappetta, Il matrimonio..., dz. cyt., s. 260: „È chiaro che il perdurare del consenso non si riferisce all'atto di volontà che ha posto in essere il matrimonio «in fieri». Un tale atto psichico ha carattere transitorio ed evidentemente non può perdurare. Perdura invece il consenso prestato, nella sua virtualità giuridico-morale, come stato di volontà (in sostanza, con intenzione abituale), che accompagna il matrimionio «in facto esse»".

18 Por. TAmżE.

19 Por. K. Lüdicke, Heiligungsamt: Ehe, ad. 1107 n. 4; P. BiAnCHI, Commento al. can. 1107, s. 920.

20 Por. P. Bianchi, Commento al. can. 1107, dz. cyt., s. 920.

21 Por. M. KaIser, Der gute Glaube im Codex Iuris Canonici, München 1965, s. 131.
} 
nieskutecznej z powodu przeszkody zrywającej pochodzącej z prawa kościelnego lub braku formy kanonicznej może zostać uzdrowione w zawiązku, dopóki zgoda małżeńska trwa"22.

W tym kontekście ciekawą hipotezę przytacza się w niektórych komentarzach, mianowicie, wskazuje się, że nie sanuje się związku, jeśli po zawarciu związku pojawiła się niezdolność konsensualna. Tę sytuację postrzega się bowiem jako odwołanie implicite ${ }^{23}$.

Kontynuując należy dodać, iż ze względu na to, że wyrażona zgoda jest nieważna z powodu naruszenia elementów prawnej struktury małżeństwa pochodzących z prawa pozytywnego ustawodawca przewidział możliwość jej odwołania.

\section{Odwołanie wyrażonej zgody}

Jak wiadomo w analizowanym kan. 1107 KPK prawodawca nie wyklucza odwołania zgody w stwierdzeniu „dopóki nie uzyska się pewności jej odwołania”. W „Słowniku języka polskiego PWN” znajdujemy, iż jednym z desygnatów słowa „odwołać ” jest „cofnąć”24. Tak pojmuje odwołanie m.in. Klaus Lüdicke stwierdzając, iż jest ono decyzją, w której przynajmniej jedna ze stron wyraża wolę, że nie chce być już partnerem w zawartym związku ${ }^{25}$. Zdaniem Francesco Bersinego powzięty przez małżonka krok zakłada u niego istnienie świadomości nieważności zawartego związku ${ }^{26}$. Viladrich decyzję o odwołaniu wiąże z kryzysem identyfikacji małżeńskiej. Argumentował: „Nupturienci, którzy wyrazili swoją zgodę bez jej braku czy wady i uważają się za małżonków - dopóki nie wiedzą o nieważności z powodu przeszkody albo braku formy - odnoszą się do siebie na bazie akceptacji swej tożsamości jako małżonkowie. Ten stan pełnej

\footnotetext{
22 Por. O. Robleda, El matrimonio..., dz. cyt., s. 131.

23 Por. J. Hervada, Comento al can. 1107 CIC, w: Código de Derecho Canónico. Edición biligüe anotada, Pamplona 2018, s. 703.

24 Por. Odwołać, w: Słownik języka polskiego PWN, oprac. L. Drabik, A. KuBiak-Sokó£, E. Sobol, L. Wiśniakowska, Warszawa 2014, s. 569.

25 Por. K. Lüdicke, Heiligungsamt: Ehe, ad. 1107 n. 3.

26 Por. F. Bersini, Il diritto canonico..., dz. cyt., s. 142.
} 
akceptacji, w oparciu o który identyfikują się i żyją wspólnie jako małżonkowie jest właśnie «trwaniem zgody», ponieważ ten stan jest szczególnym skutkiem w psychologicznym wnętrzu i w zakresie zachowań życiowych woli zawarcia małżeństwa i tego, że małżeństwo rzeczywiście zostało zawarte. Ten radykalny stan identyfikowania się jako małżonkowie [...], jest w praktyce do pogodzenia z większym lub mniejszym szczęściem, z większym lub mniejszym przenikaniem się w życiu małżeńskim, ze wszystkim co jest dobre i co złe w życiu ważnego małżeństwa. Toteż odwołanie zgody polega na kryzysie tej identyfikacji małżeńskiej, na mocy której jeden lub oboje «małżonkowie» swoim zachowaniem, czy zewnętrznymi objawami dowodzą, że już jej nie akceptują"27.

Według zasad określonych $\mathrm{w}$ teorii aktu prawnego odwołanie winno nastąpić $\mathrm{w}$ wyniku pozytywnego aktu woli ${ }^{28}$; prawnie relewantnymi zatem nie są intencja interpretatywna oraz domniemana ${ }^{29}$.

Kanoniści rozróżniają pomiędzy odwołaniem explicite oraz implicite $^{30}$. Rozważając tę kwestię należy zauważyć, iż w analizowanej regulacji występuje następujące zastrzeżenie co do odwołania: „dopóki nie uzyska się pewności jej odwołania”. Autorzy publikacji poświęconych temu zagadnieniu wskazują, iż trudności nie nastręcza udowodnienie odwołania wyraźnego. Dla przykładu może to mieć miejsce w procesie o stwierdzenie nieważności małżeństwa, po dokonaniu konwalidacji małżeństwa. Spore problemy interpretacyjne natomiast generuje kwestia cofnięcia zgody implicite. W tym wypadku bowiem $\mathrm{z}$ reguły mamy do czynienia z oceną faktów niejednoznacznych. Komentatorzy w swych opracowaniach przytaczają niektóre kazusy, wyrażając różne nie zawsze zgodne opinie w kwestii ich relewantności. I tak zdaniem Luigi Sabbarese, na trwający konsens wskazuje istniejące pożycie

\footnotetext{
27 Zob. P.J. Viladrich, Konsens małżeński..., dz. cyt., s. 469-470.

28 Por. G. Michiels, Principia generalia de personis in Ecclesia, Parisiis-Tornaci-Romae 1955, s. 588: „Nullus est dubium, quin intentio agentis positive moveri debeat fine quodam determinato [...]".

29 Por. L. Chiappetta, Il matrimonio..., dz. cyt., s. 260.

30 Por. L. Chiappetta, Il matrimonio..., dz. cyt., s. 261; P. BiAnChi, Commento al. can. 1107, dz. cyt., s. 920.
} 
małżeńskie ${ }^{31}$. Ewentualności odwołania nie wykluczono w wyroku c. Hout z 24 listopada 1981 roku stwierdzając, awersję do małżeństwa wyklucza wprawdzie pokojowe współżycie małżonków; jeśli jednak wykaże się występowanie takiej postawy, wówczas udowodnienie takiej decyzji jest możliwe; jeśli natomiast pożycie małżonków przedłużałoby się, wtedy domniemanie wskazywałoby na odnowiony konsens $^{32}$. Z kolei Winfrid Aymans oraz Klaus Mörsdorf za takie uznali zawarcie związku cywilnego ${ }^{33}$. Mimo że podjął tę kwestię w swym „Komentarzu” Chiappetta to jednak jej nie rozwiązał, gdyż każdy wymieniony przez niego kazus kończy się pytaniem. Wymienił on: niewypełnianie obowiązków małżeńskich, występującą awersję między małżonkami, separację faktyczną lub prawną, wprowadzenie skargi o stwierdzenie nieważności małżeństwa, domaganie się rozwodu cywilnego, pożycie more uxorio z osobą trzecią, brak woli ponownego wyrażenia konsensu. Wyjaśniając ten problem zwrócił uwagę, iż dopóki trwa pożycie małżeńskie nie domniemywa się, że konsens został odwołany ${ }^{34}$.

Na zakończenie należy spostrzec, iż podobną zasadę choć wyraźnie nienazwaną stosuje się w orzecznictwie kościelnym w motywach prawnych wyroków z tytułów warunku i symulacji (kan. 1102 i 1101 KPK). I tak co do warunku, to gdy udowodniono jego postawienie przed zawarciem małżeństwa, to w procesach sądowych domniemywano, że warunek skutkował w chwili wyrażenia zgody małżeńskiej. Innymi słowy, odwołania warunku nie domniemywano, ale należało je udowodnić. Podobne są mechanizmy funkcjonowania

31 Por. L. Sabbarese, Il matrimonio canonico..., dz. cyt., s. 295.

32 Por. Dec. C. Hout z 24.11.1981, RRDec., vol. LXXIII, s. 578, n. 24: „Circumstantiae praesertim vitae iugalis sunt etiam attente conspiciendae: ubi enim intima vitae communio iam ab initio instauratur atque pacifice prosequitur, aversio ita potius negari videtur; quodsi autem vix vel ne vix quidem verificatur cohabitatio, indicium aversionis hoc e contra erit. Praeterea, si vita communis protrahitur, praesumptio adesse poterit etiam renovati consensus (cfr. analogice cum can. 1093)".

33 Por. W. Aymans, K. Mörsdorf, Kanonisches Recht, t. 3, Padeborn 2007, s. 464.

34 Por. L. Chiappetta, Il matrimonio..., dz. cyt., s. 261. 
tzw. simulatio virtulualis; w tym wypadku idzie o wykluczenie dokonane przed zawarciem związku, wywierające skutek prawny w chwili zawierania małżeństwa. $Z$ reguły zarówno w przypadku symulacji całkowitej, jak i częściowej nieważność małżeństwa wynika z wirtualnego aktu woli, a nie aktualnego. Należy dodać, iż podobnie w pryzmacie wirtualności postrzegał trwanie konsensu Olis Robleda ${ }^{35}$.

\section{Zakończenie}

Z przeprowadzonych analiz wynika, iż podjęte w tym opracowaniu zagadnienie sporadycznie podejmowane jest przez kanonistów. W niektórych komentarzach, w których poddano szczegółowej analizie poszczególne kanony Kodeksu w ogóle nie odniesiono się do kan. 1107 KPK. W orzecznictwie rotalnym jedynie w nielicznych wyrokach zacytowano interesujący nas kanon, traktując jego zapis, co jest w pełni zrozumiałe ze względu na charakter toczących się spraw, marginalnie.

Występujący w materialnym prawie małżeńskim kan. 1107 KPK jest wyrazem troski prawodawcy kościelnego o ochronę wymiaru prawnoformalnego węzła małżeńskiego. Reinhold Sebott uważa, iż zapis tej regulacji pozostaje w ścisłym organicznym związku z kan. 1100 KPK; w porównaniu do ostatniej regulacji prawodawca w swych ustaleniach posunął się nieco dalej (geht weiter), optując za pewniejszą hipotezą, w której wyrażony w uwarunkowaniach określonych w normie konsens trwa ${ }^{36}$. W tym kontekście prowadzonych analiz rodzi się jeszcze pytanie o ratio legis kan. $1107 \mathrm{KPK}$. Odpowiadając na to pytanie kanoniści wskazują, iż głównym powodem utrzymania tej regulacji w obowiązującej kodyfikacji jest umożliwienie konwalidacji

\footnotetext{
35 Por. O. Robleda, El matrimonio..., dz. cyt., s. 132.

36 Por. R. Sевотт, Das neue kirchliche Eherecht, Frankfurt a. M/Frankfurt 2005, s. 145.
} 
nieważnego związku z powodu zaistnienia przeszkody zrywającej lub braku formy kanonicznej ${ }^{37}$.

\section{Status of void marriages due to the existing impediment or lack of canonical form in the canon law order (can. 1107 of the Code of Canon Law)}

\section{Summary}

In the presented study, the author analysed can. 1107 of the Code of Canon Law on the status of marriages invalid due to the impediment or lack of a canonical form in the canon law order.

The conducted research shows that its existence results from the Church legislator's concern for the protection of the legal and formal dimension of the marriage bond. It was proved that the ratio legis of this canon is to enable the convalidation of an invalid marriage due to the existence of an diriment impediment or the lack of a canonical form.

Słowa kluczowe: małżeństwo kanoniczne, trwanie zgody małżeńskiej, przeszkoda zrywająca, brak formy kanonicznej, domniemanie.

Key words: canonical marriage, duration of marriage consent, diriment impediment, lack of canonical form, presumption.

\section{Nota o autorze}

Ks. Ginter Dzierżon - profesor zwyczajny prawa kanonicznego, kierownik Katedry Historii, Teorii i Norm Ogólnych Prawa Kanonicznego na Wydziale Prawa Kanonicznego UKSW; Obrońca Węzła Małżeńskiego Sądu Biskupiego Diecezji Gliwickiej.

37 Por. P. GAsparri, Tractatus canonicus de matrimonio, t. 2, Romae 1932, s. 99; A.S. SÀnCHEZ-GIL, La presunzione di validità dell'atto giridico nel diritto canonico, Milano 2006, s. 155. 